\title{
Erratum: Stress analysis on Canadian naval platforms using a portable miniature X-ray diffractometer [Powder Diffr. 25(2), 119-124 (2010)]
}

Shannon P. Farrell

Dockyard Laboratory (Atlantic), Defence Research and Development Canada-Atlantic, 9 Grove St., Dartmouth, Nova Scotia B2Y 3Z7, Canada

(Received 24 July 2010; accepted 24 July 2010)

Please note the copyright statement should read: Her Majesty the Queen in Right of Canada, as represented by the Minister of National Defence, [2010]. (C) Sa Majesté la Reine (en droit du Canada), telle que représentée par le ministre de la Défense nationale, [2010].

[DOI: $10.1154 / 1.3479110]$ 